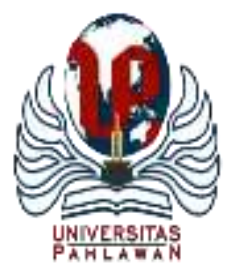

Edukatif : Jurnal Ilmu Pendidikan Volume 4 Nomor 1 Tahun 2022 Halm 1281 - 1288

EDUKATIF: JURNAL ILMU PENDIDIKAN

Research \& Learning in Education

https://edukatif.org/index.php/edukatif/index

\title{
Upaya Meningkatkan Kinerja Guru Melalui Reward dan Punishment di Madrasah
}

\author{
Abdul Latif Hutagaol ${ }^{1 凶}$, Sri Rezeqi Rafiqah Wardah $^{2}$, Neliwati ${ }^{3}$ \\ Universitas Islam Negeri Sumatera Utara Medan, Indonesia ${ }^{1,2,3}$ \\ E-mail : abdullatifhutagaol@gmail.com ${ }^{1}$, srirezekinining@gmail.com ${ }^{2}$, neliwati@uinsu.ac.id ${ }^{3}$
}

\begin{abstract}
Abstrak
Kinerja guru merupakan problematika dunia pendidikan yang meniscayakan berbagai upaya untuk peningkatan kualitas pendidikan. Sebab, peningkatan kualitas pendidikan berbanding lurus dengan peningkatan kinerja guru. Penelitian ini bertujuan untuk menganalisa upaya meningkatkan kinerja guru melalui reward dan punishment di MTs Qur'an Kisaran. Penelitian ini menggunakan pendekatan kualitatif dengan jenis Penelitian Tindakan Kelas (PTK). Pemerolehan data dilakukan menggunakan teknik wawancara, observasi, dan studi dokumen. Hasil penelitian menunjukkan bahwa Implementasi reward yang diterapkan di MTs Qur'an Kisaran berupa penghargaan finansial seperti tunjangan, insentif, dan bonus. Penghargaan non-finansial seperti piagam, plakat sebagai pengakuan, dan promosi jabatan. Sedangkan untuk Implementasi punishment atau hukuman berupa peringatan, teguran, pemotongan gaji, pengurangan beban kerja, pergantian amanah jabatan, hingga pemutusan hubungan kontrak kerja antara guru dengan madrasah. Implikasi dari penelitian ini berdampak positif, yaitu berupa peningkatan kinerja sejumlah 62 guru di madrasah tersebut (semula belum efektif $36 \%$, berkurang menjadi 9,4\%).
\end{abstract}

Kata Kunci: Kinerja Guru, Punishment, Reward.

\section{Abstract}

Teacher performance is a problem in the world of education which requires various efforts to improve the quality of education. This is because improving the quality of education is directly proportional to the improvement in teacher performance. This study aims to analyze efforts to improve teacher performance through rewards and punishments at MTs Qur'an Kisaran. This study uses a qualitative approach with the type of Classroom Action Research (CAR). Data collection was carried out using interview, observation, and document studies. The results show that the implementation of rewards applied at MTs Qur'an Kisaran is in the form of financial rewards such as allowances, incentives, and bonuses. Non-financial awards such as certificates, plaques in recognition, and promotions. As for the implementation of punishment or punishment in the form of warnings, reprimands, salary cuts, workload reduction, change of position mandate, to termination of the work contract between teachers and madrasas. The implications of this research have a positive impact, namely in the form of improving the performance of a number of 62 teachers in the madrasa (originally not yet effective $36 \%$, reduced to $9.4 \%$ ).

Keywords: Teacher Performance, Punishment, Reward.

Copyright (c) 2022 Abdul Latif Hutagaol, Sri Rezeqi Rafiqah Wardah, Neliwati

$\triangle$ Corresponding author

Email : abdullatifhutagaol@gmail.com

DOI : https://doi.org/10.31004/edukatif.v4i1.2159

ISSN 2656-8063 (Media Cetak)

ISSN 2656-8071 (Media Online) 
1282 Upaya Meningkatkan Kinerja Guru Melalui Reward dan Punishment di Madrasah - Abdul Latif Hutagaol, Sri Rezeqi Rafiqah Wardah, Neliwati

DOI: https://doi.org/10.31004/edukatif.v4i1.2159

\section{PENDAHULUAN}

Perubahan tingkah laku merupakan dampak (akibat) yang diperoleh melalui sebab adanya interaksi antara stimulus dan respon (Timpe, 2002; Wahyudi \& Neviyarni, 2021; Syahana \& Andromeda, 2021). Dalam teori belajar behavioristik, diterangkan bahwa reward dan punishment merupakan bentuk penguatan perilaku positif yang diberikan guru kepada siswa, guna menstimulus karakter selama proses pembelajaran. Dalam konteks ini, dipahami bahwa kemampuan, keterampilan dan sikap peserta didik, besar dipengaruhi oleh proses interaksi yang dilalui selama proses pembelajaran, termasuk stimulus-respons menggunakan reward dan punishment.

Menurut Budiningsih (2005), reward sederhananya berarti penghargaan. Secara fungsional dalam proses pembelajaran, reward dijadikan sebagai alat mendidik siswa untuk bertingkah laku positif, melalui penghargaan atas kinerja (prestasi) yang ditunjukkan oleh siswa. Begitupun, reward tidak hanya diperuntukkan antara guru terhadap siswa, sebab penghargaan ini memiliki makna luas sebagai alat menstimulus peningkatan (atau minimal mempertahankan) kinerja setiap individu.

Reward merupakan salah satu faktor eksternal dalam upaya mempengaruhi perilaku, sikap, dan minat belajar peserta didik. Atas dasar ini, reward memiliki peranan penting dalam proses pembelajaran, bahkan dipandang sebagai cara humanis dalam meningkatkan kompetensi, prestasi dan hasil belajar siswa. Lebih lanjut, Siregar (2017) menambahkan bahwa sistem pemberian reward secara tidak langsung menciptakan iklim belajar kondusif dan melatih keterampilan siswa dalam kompetisi belajar.

Secara umum, reward dapat dibedakan menjadi empat macam, yaitu: pertama, Pujian, adalah satu bentuk reward yang paling mudah dilakukan. Pujian dapat berupa kata-kata seperti: "baik, bagus, bagus sekali" dan sebagainya. Akan tetapi dapat juga berupa kata-kata yang bersifat sugesti, misalnya: "Nah, lain kali akan lebih baik lagi jika Bapak/Ibu seperti ini dan in" dan lain sebagainya. Kedua, Penghormatan, reward yang berupa penghormatan ini dapat berbentuk dua macam, yaitu berbentuk penobatan dan penghormatan yang berbentuk pemberian kekuasaan untuk melakukan sesuatu. Penghormatan juga dapat berbentuk kepercayaan, seperti guru diberi bantuan beasiswa untuk studi lanjut sekaligus sebagai bentuk pengembangan profesi guru (Rahman, 2017; Bahagia, et.al., 2021).

Ketiga, Hadiah, yang dimaksud dengan hadiah di sini ialah reward yang berbentuk pemberian yang berupa barang. Reward yang berupa pemberian barang ini disebut juga reward materiil, yaitu hadiah yang berupa barang. Barang ini dapat terdiri dari alat-alat keperluan dalam mengajar, yang memungkinkan bermanfaat serta dapat dipergunakan oleh guru tersebut. Ke empat, Tanda penghargaan, jika hadiah adalah reward yang berupa barang, maka tanda penghargaan adalah kebalikannya. Tanda penghargaan tidak dinilai dari segi harga dan kegunaan barang-barang tersebut seperti halnya pada hadiah, melainkan tanda pengahargaan dinilai dari segi kesan atau nilai kenangnya. Oleh karena itu, reward atau tanda penghargaan ini disebut juga reward simbolis. Reward simbolis ini dapat berupa surat-surat tanda jasa, sertifikat-sertifikat, dan surat berharga lain dalam konteks akademik (Simamora, 2012; Laily, 2021).

Berdasarkan keempat macam reward di atas, dalam implementasinya seorang pemimpin atau kepala madrasah boleh memilih jenis reward yang akan diberikan kepada guru yang berhak mendapatkannya. Pemilihan reward yang diberikan, juga melihat kondisi dan situasi sumber daya keuangan madrasah. Jika memungkinkan untuk memberikan empat jenis reward di atas, maka itulah reward terbaik dan memiliki efek positif yang maksimal buat guru maupun madrasah ke depan.

Tujuan yang harus dicapai dalam pemberian reward adalah untuk meningkatkan kinerja guru sesuai dengan tugas pokok dan fungsinya, sehingga dapat memenuhi standar pendidik pada 8 (delapan) Standar Nasional Pendidikan. Dalam artian, guru melakukan suatu perubahan menuju kepada yang lebih baik, maka perubahan itu timbul dari kesadaran guru itu sendiri. Dengan adanya reward, diharapkan dapat menjadi 
1283 Upaya Meningkatkan Kinerja Guru Melalui Reward dan Punishment di Madrasah - Abdul Latif Hutagaol, Sri Rezeqi Rafiqah Wardah, Neliwati

DOI: https://doi.org/10.31004/edukatif.v4i1.2159

motivasi bagi semua guru serta dapat membangun suatu hubungan yang positif antara pimpinan organisasi pendidikan dan guru.

Jadi, tujuan dan fungsi reward itu yang terpenting bukanlah hasil yang dicapai seorang guru, akan tetapi proses perbaikan untuk menjadikan diri lebih baik secara mandiri. Merasa memiliki dan tanggung jawab penuh terhadap tufoksi yang diberikan madrasah. Bekerja serius bukan hanya untuk dilihat oleh pimpinan. Tetapi tetap serius bekerja baik dilihat atau pun tidak dilihat oleh pimpinan. Reward juga diberikan, bukan untuk menjadikan seorang guru menjadi sombong, memberikan derajat yang berbeda karena merasa lebih baik dari yang lain, melainkan tetap rendah hati dan berbagi untuk saling bermotivasi dalam meningkatkan kinerja.

Selanjutnya terkait punishment, Rivai (2015) berpendapat bahwa punishment adalah penderitaan yang diberikan atau ditimbulkan dengan sengaja oleh seseorang (orang tua, guru, dan sebagainya) sesudah terjadi suatu pelanggaran, kejahatan atau kesalahan. Sedangkan menurut Mangkuprawira (2004), punishment (hukuman) adalah suatu perbuatan, di mana individu secara sadar dan sengaja menjatuhkan nestapa kepada orang lain, yang baik dari segi kejasmanian maupun dari segi kerohanian orang lain itu mempunyai kelemahan bila dibandingkan dengan diri kita, atas dasar itu pendidik mempunyai tanggung jawab untuk membimbing dan melindunginya.

Secara umum, punishment dibagi menjadi 2 (dua) macam, yaitu: Pertama, Punishment preventif; yaitu punishment yang dilakukan dengan maksud agar tidak atau jangan terjadi pelanggaran. Punishment ini bermaksud untuk mencegah jangan sampai terjadi pelanggaran sehingga hal itu dilakukannya sebelum pelanggaran dilakukan. Kedua, Punishment refresif; yaitu punishment yang dilakukan oleh karena adanya pelanggaran, oleh adanya dosa yang telah diperbuat. Jadi, punishment ini dilakukan setelah terjadi pelanggaran atau kesalahan.

Pendapat lain tentang macam-macam punishment adalah pendapat Wiliam Stern membedakan tiga macam yang disesuaikan dengan tingkat yang menerima punishment. Punishment terdiri dari tiga macam, yaitu: asosiatif; logis; dan normatif. Jika tingkat kesalahan masih dapat didiskusikan dengan kerjasama, maka dapat menggunakan punishment asosiatif, jika tingkat kesalahan hanya dapat dihubungkan dengan logika, maka dengan punishment logis, atau jika kesalahan sesuai dengan peraturan yang berlaku, maka dengan punishment normatif. Dalam memberikan punishment, setiap orang memiliki tujuan yang berbeda-beda. Hal ini telah lama diteorikan oleh para pakar pendidikan yang secara umum dibagi ke dalam lima kategori teori tujuan pemberian punishment (hukuman), yaitu teori pembalasan, teori perbaikan, teori perlindungan, teori ganti-rugi dan teori menakut-nakuti (Bleotu \& Maria, 2014; Susanti, 2021).

Setelah memahami teori punishment dari beberapa peneliti di atas, kita dapat menyimpulkan bahwa tidak semua jenis punishment dapat diimplemetasikan pada suatu organisasi. Perlu pertimbangan dan analisis yang tajam dari korelasi punishment dengan ketentuan yang berlaku. Namun dari berbagai pengalaman dan fakta yang ada dominan menggunakan punishment normatif, yakni punishment sesuai dengan peraturan yang berlaku.

Hasil pengamatan penulis menunjukkan bahwa kinerja guru di MTs Qur'an Kisaran masih kurang maksimal, hal ini diindikasikan oleh: (1) dilihat dari persentase kedisiplinan waktu masih rendah, tidak sedikit guru yang masih hadir terlambat dalam bekerja dengan alasan-alasan yang klasik. (2) terdapat sebagian guru yang sering tidak hadir bertugas, baik karena sakit, izin bahkan tanpa keterangan sama sekali. (3) terdapat beberapa guru yang tidak hadir dalam rapat rutin, juga ada guru yang tidak pernah datang dalam rapat. (4) administrasi guru tidak lengkap, ada beberapa guru yang mengumpulkan administrasi bahan ajarnya namun tidak lengkap sesuai dengan kriteria buku kerja guru. Dan mirisnya lagi ada guru yang sama sekali tidak mengumpulkan administrasi pembelajarannya. (5) sedikitnya guru yang berpartisipasi dan berkontribusi dalam kegiatan-kegiatan yang diprogramkan madrasah.

Menurut teori belajar behavioristik, pemberian reward dan punishment dapat digunakan untuk memperkuat dan melemahkan respons positif atau respons negatif (Aziz, 2016). Pemberian reward akan 
1284 Upaya Meningkatkan Kinerja Guru Melalui Reward dan Punishment di Madrasah - Abdul Latif Hutagaol, Sri Rezeqi Rafiqah Wardah, Neliwati

DOI: https://doi.org/10.31004/edukatif.v4i1.2159

memperkuat perilaku positif dan pemberian punishment melemahkan perilaku negatif. Pemberian reward dan punishment terbukti efektif dalam praktek pendidikan/pembelajaran, sebagai bukti yang autentik adalah pemberian reward dan punishment dapat meningkatkan kinerja guru di SDIT Al-Muhsin Metro (Fadli, 2021; Khairi, 2021).

Berdasarkan dari masalah yang dijelaskan sebelumnya, ditambahkan dengan beberapa teori yang ditulisakan, juga diikuti dengan bukti-bukti yang empiris dari beberapa penelitian. Maka peneliti memiliki keyakinan bahwa Implementasi reward dan punishment dapat meningkatkan kinerja guru di MTs Qur'an Kisaran. Implementasi reward dan punishment ini diharapkan dapat mengubah dan menggugah para guru untuk menjadi lebih baik lagi secara mandiri, ikhlas dalam bekerja, siap berkompetisi, berpartisipasi dan berkontribusi secara penuh kepada madrasah untuk kemajuan madrasah serta masa depan yang cerah di masa mendatang.

\section{METODE PENELITIAN}

Penelitian ini menggunakan metode penelitian kualitatif jenis penelitian tindakan kelas (PTK) yang dilaksanakan dalam 2 siklus (Assingkily, 2021). Masing-masing siklus dilaksanakan selama 2 minggu. Subjek penelitian terdiri atas 62 orang guru di MTs Qur'an Kisaran yang mengajar di 23 kelas dan 15 mata pelajaran. Pengambilan data menggunakan teknik dokumentasi, angket, wawancara, dan observasi kegiatan guru mengajar. Instrumen penelitian terdiri atas lembar kehadiran guru, baik terlambat atau tidak hadir mengajar, lembar observasi kehadiran guru ketika rapat, lembar observasi data serah terima administrasi pembelajaran dan lembar wawancara kontribusi kegiatan. Data dianalisis secara deskriptif dan dinyatakan dalam bentuk persentase.

Prosedur atau langkah-langkah penelitian dilakukan dalam bentuk siklus. Setiap siklus memuat 4 kegiatan pokok yaitu perencanaan, pelaksanaan, observasi, dan refleksi. Sebelum melaksanakan siklus penelitian, Peneliti melakukan identifikasi masalah utama, yaitu lemahnya kinerja kerja guru. Identifikasi tersebut didasarkan pada dokumentasi kehadiran guru, ketepatan waktu kehadiran sesuai jadwal mengajar, kehadiran guru ketika rapat, kelengkapan administrasi guru, keikutsertaan berpartisipasi dalam kegiatan madrasah dan hasil diskusi dengan kepala, wakil kepala serta guru.

Hasil temuan awal tersebut dijadikan dasar untuk membuat rencana tindakan penelitian. beserta perangkat yang diperlukan untuk kelancaran pelaksanaan, serta instrumen untuk mengukur/merekam hasil tindakan. Indikator keberhasilan tindakan yang ditetapkan peneliti adalah terjadinya peningkatan kinerja guru di MTs Qur'an Kisaran. Pada tahapan perencanaan siklus I, peneliti membuat skenario peningkatan kinerja guru dengan pemberian reward dan punishment beserta perangkat-perangkat pendukung lainnya.

Peneliti juga menyiapkan sejumlah instrumen untuk merekam sekaligus mengevaluasi pelaksanaan tindakan. Perangkat dan instrumen yang dimaksud terdiri dari lembar kedisiplinan hadir tepat waktu, lembar presensi/kehadiran guru mengajar, lembar presensi/ kehadiran guru ketika rapat, lembar observasi kelengkapan administrasi mengajar, lembar kehadiran dan kontribusi dalam kegiatan, juga angket buat diisi oleh kepala madrasah, wakil dan guru.

\section{HASIL DAN PEMBAHASAN PENELITIAN}

Pelaksanaan tindakan penelitian ini melibatkan wakil kepala madrasah bidang kurikulum sebagai observer sekaligus sebagai teman diskusi untuk merefleksi berbagai temuan serta merumuskan tindaklanjutnya. Pelaksanaan serta refleksi tindakan pada siklus I disajikan pada Tabel 1. 
1285 Upaya Meningkatkan Kinerja Guru Melalui Reward dan Punishment di Madrasah - Abdul Latif Hutagaol, Sri Rezeqi Rafiqah Wardah, Neliwati

DOI: https://doi.org/10.31004/edukatif.v4i1.2159

Tabel 1. Hasil Penelitian Pada Setiap Parameter Peningkatan Kinerja Guru Siklus I

\begin{tabular}{|c|c|c|c|c|}
\hline No & Aspek Tinjauan & Tindakan Ke-1 & Capaian & Refleksi \\
\hline 1 & $\begin{array}{l}\text { Kehadiran guru } \\
\text { tepat waktu }\end{array}$ & $\begin{array}{l}\text { Kepala Madrasah } \\
\text { hadir } 30 \text { menit } \\
\text { sebelum bel masuk }\end{array}$ & $70 \%$ & $\begin{array}{l}\text { Keteladanan kepala madrasah } \\
\text { dalam penegakan disiplin, reward } \\
\text { dan punishment }\end{array}$ \\
\hline 2 & $\begin{array}{l}\text { Kehadiran guru } \\
\text { mengajar }\end{array}$ & Supervisi kelas & $80 \%$ & $\begin{array}{l}\text { Pengawasan } \text { Intens } \\
\text { madrasah dalam penegakan } \\
\text { disiplin, reward dan punishment }\end{array}$ \\
\hline 3 & $\begin{array}{l}\text { Kehadiran guru } \\
\text { dalam rapat }\end{array}$ & $\begin{array}{l}\text { Periksa notulen } \\
\text { dan daftar hadir } \\
\text { rapat }\end{array}$ & $60 \%$ & 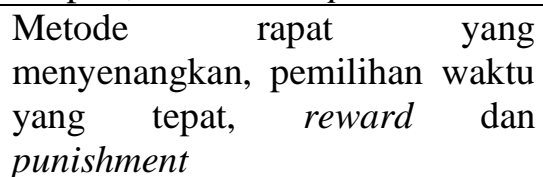 \\
\hline 4 & $\begin{array}{l}\text { Kelengkapan } \\
\text { administrasi } \\
\text { guru }\end{array}$ & $\begin{array}{l}\text { Periksa } \\
\text { administrasi guru }\end{array}$ & $60 \%$ & $\begin{array}{l}\text { Penyedian sarana kegiatan belajar } \\
\text { yang dibutuhkan guru, reward } \\
\text { dan punishment }\end{array}$ \\
\hline 5 & $\begin{array}{l}\text { Keaktifan dalam } \\
\text { kegiatan } \\
\text { madrasah }\end{array}$ & $\begin{array}{l}\text { Diskusi dengan } \\
\text { struktur madrasah } \\
\text { (pemangku } \\
\text { jabatan) }\end{array}$ & $50 \%$ & $\begin{array}{l}\text { Melibatkan guru untuk diberikan } \\
\text { amanah dalam kegiatan-kegiatan } \\
\text { madrasah, reward dan } \\
\text { punishment }\end{array}$ \\
\hline
\end{tabular}

Hasil penelitian menunjukkan bahwa pada tindakan ke-1 keterlaksanaan setiap aspek yang diteliti masih berkisar antara 50\%-80\%. Berdasarkan hasil refleksi dirumuskan bahwa perlu dilakukan beberapa hal sebagai tindak lanjut untuk meningkatkan keterlaksanaan aspek yang diteliti, yaitu (1) Perlu keteladanan dan penegakan disiplin dari kepala madrasah secara konsisten dalam hal kehadiran tepat waktu, (2) Perlu pengawasan yang Intens dari kepala madrasah, wakil kepala bidang kurikulum, atau guru piket harian dalam supervisi kehadiran guru mengajar dikelas. (3) Perlu Inovasi dalam metode rapat bersama guru agar rapat menyenangkan dan membahagiakan patisipan serta analisis waktu yang tepat dalam agenda rapat. (4) perlu penyediaan sarana kegiatan belajar dalam hal kelengkapan administrasi guru, (5) Perlu melibatkan guru dalam kepanitian untuk melaksanakan kegiatan-kegiatan yang di programkan oleh madrasah.

Dari kelima aspek tinjauan peneliti perlu diberikan reward dan punishment untuk meningkatkan kinerja guru di MTs Qur'an Kisaran. Pelaksanaan tindakan siklus 2 yang menerapkan temuan hasil refleksi pada siklus 1 menghasilkan peningkatan kinerja guru seperti disajikan pada Tabel 2.

Tabel 2. Hasil Penelitian Pada Setiap Parameter Peningkatan Kinerja Guru Siklus II

\begin{tabular}{|c|c|c|c|c|}
\hline No & Aspek Tinjauan & Tindakan Ke-2 & Capaian & Refleksi \\
\hline 1. & $\begin{array}{l}\text { Kehadiran guru } \\
\text { tepat waktu }\end{array}$ & $\begin{array}{l}\text { Kepala } \quad \text { Madrasah } \\
\text { hadir } 30 \text { menit } \\
\text { sebelum bel masuk }\end{array}$ & $90 \%$ & $\begin{array}{l}\text { Keteladanan unsur wakil kepala } \\
\text { madrasah, reward dan } \\
\text { punishment }\end{array}$ \\
\hline 2. & $\begin{array}{l}\text { Kehadiran guru } \\
\text { mengajar }\end{array}$ & $\begin{array}{ll}\text { Supervisi kelas } \\
\text { berkelanjutan }\end{array}$ & $98 \%$ & $\begin{array}{l}\text { Konfirmasi, koordinasi reward } \\
\text { dan punishment }\end{array}$ \\
\hline 3. & $\begin{array}{l}\text { Kehadiran guru } \\
\text { dalam rapat }\end{array}$ & $\begin{array}{l}\text { Evaluasi daftar } \\
\text { hadir rapat }\end{array}$ & $85 \%$ & $\begin{array}{l}\text { Komitmen dengan nuasa rapat } \\
\text { untuk lebih inovatif, reward dan } \\
\text { punishment }\end{array}$ \\
\hline 4. & $\begin{array}{l}\text { Kelengkapan } \\
\text { administrasi } \\
\text { guru }\end{array}$ & $\begin{array}{lr}\text { Evaluasi } & \text { dan } \\
\text { kontrol } & \text { tugas } \\
\text { pokok/ administrasi } \\
\text { guru }\end{array}$ & $95 \%$ & $\begin{array}{l}\text { Pembinaan/ pelatihan, reword } \\
\text { dan punishment }\end{array}$ \\
\hline 5. & $\begin{array}{l}\text { Keaktifan dalam } \\
\text { kegiatan } \\
\text { madrasah }\end{array}$ & $\begin{array}{lr}\text { Evaluasi } & \text { amanah } \\
\text { yang } & \text { diberikan } \\
\text { kepada guru pada } \\
\text { kegiatan madrasah }\end{array}$ & $85 \%$ & $\begin{array}{l}\text { Konsolidasi, } \\
\text { punishment }\end{array}$ \\
\hline
\end{tabular}


1286 Upaya Meningkatkan Kinerja Guru Melalui Reward dan Punishment di Madrasah - Abdul Latif Hutagaol, Sri Rezeqi Rafiqah Wardah, Neliwati

DOI: https://doi.org/10.31004/edukatif.v4i1.2159

Berdasarkan hasil observasi dan angket yang disebarkan dalam dua siklus kegiatan pelaksanaan tindakan sekolah diperoleh data bahwa kehadiran guru tepat waktu dan hadir jam pertama mengalami kenaikan. Pada siklus 1 persentase kehadiran guru tepat waktu 70\%, sedangkan pada siklus 2 menjadi $90 \%$. Pada siklus 1 Persentase kehadiran guru mengajar $80 \%$ sedangkan pada siklus 2 menjadi $98 \%$. Pada siklus 1 persentase kehadiran guru dalam rapat $60 \%$ sedangkan pada siklus 2 menjadi $85 \%$. Peningkatan kinerja tepat waktu, kehadiran guru mengajar dan kehadiran guru dalam rapat melalui metode reward dan punishment ini sama dengan temuan penelitian Suryadilaga, et.al. (2016) yaitu penerapan metode reward dan punishment sama-sama mampu meningkatkan kinerja. Perbedaannya adalah jika penelitian ini diterapkan pada kinerja guru, maka penelitian yang dilakukan oleh Suryadilaga, Al Musadieq dan Nurtjahjojo diterapkan pada karyawan. Hal ini diakibatkan adanya keteladanan yang diberikan kepala madrasah dan sistem reward yang diberikan kepada guru yang disiplin. Efektivitas pemberian reward dalam meningkatkan kinerja ini sesuai pendapat Simamora (2000:121) yang menyatakan bahwa salah satu faktor yang mempengaruhi kinerja yang baik adalah struktur balas jasa.

Kelengkapan administrasi guru mengalami peningkatan di mana pada siklus 1 sebesar $60 \%$ dan pada siklus 2 sebesar 95\%. Hal ini disebabkan karena adanya evaluasi dan kontrol terhadap tugas guru melalui reward dan punishment sehingga guru lebih disiplin dalam melengkapi berkas administrasi. Sesuai hasil temuan penelitian yang dilakukan Mahirah \& Fatnah (2018), pada dasarnya supervisi kepala madrasah sepanjang dilakukan secara kontiniu dapat meningkatkan disiplin.

Keaktifan dalam kegiatan madrasah pada siklus pertama menunjukkan 50\% dan pada siklus kedua $85 \%$. Hal ini terjadi karena guru menyadari amanah dan tanggung jawab sangat penting dalam peningkatan kinerja secara individu maupun kelompok. Para guru jadi mempunyai komitmen untuk menjadi sumber daya manusia yang profesional. Disadari bersama bahwa yang menjadi alasan menurunya kinerja guru, karena tidak ada perbedaan dalam menyikapi guru yang rajin dengan malas, atau guru yang disiplin dengan melanggar aturan yang berlaku. Sehingga melalui Implementasi reward dan punishment yang dalam penelitian ini dapat meningkatkan kinerja guru di MTs Qur'an Kisaran. Secara lebih jelasnya, peningkatan kinerja guru di kedua siklus penelitian disajikan pada Gambar 1.

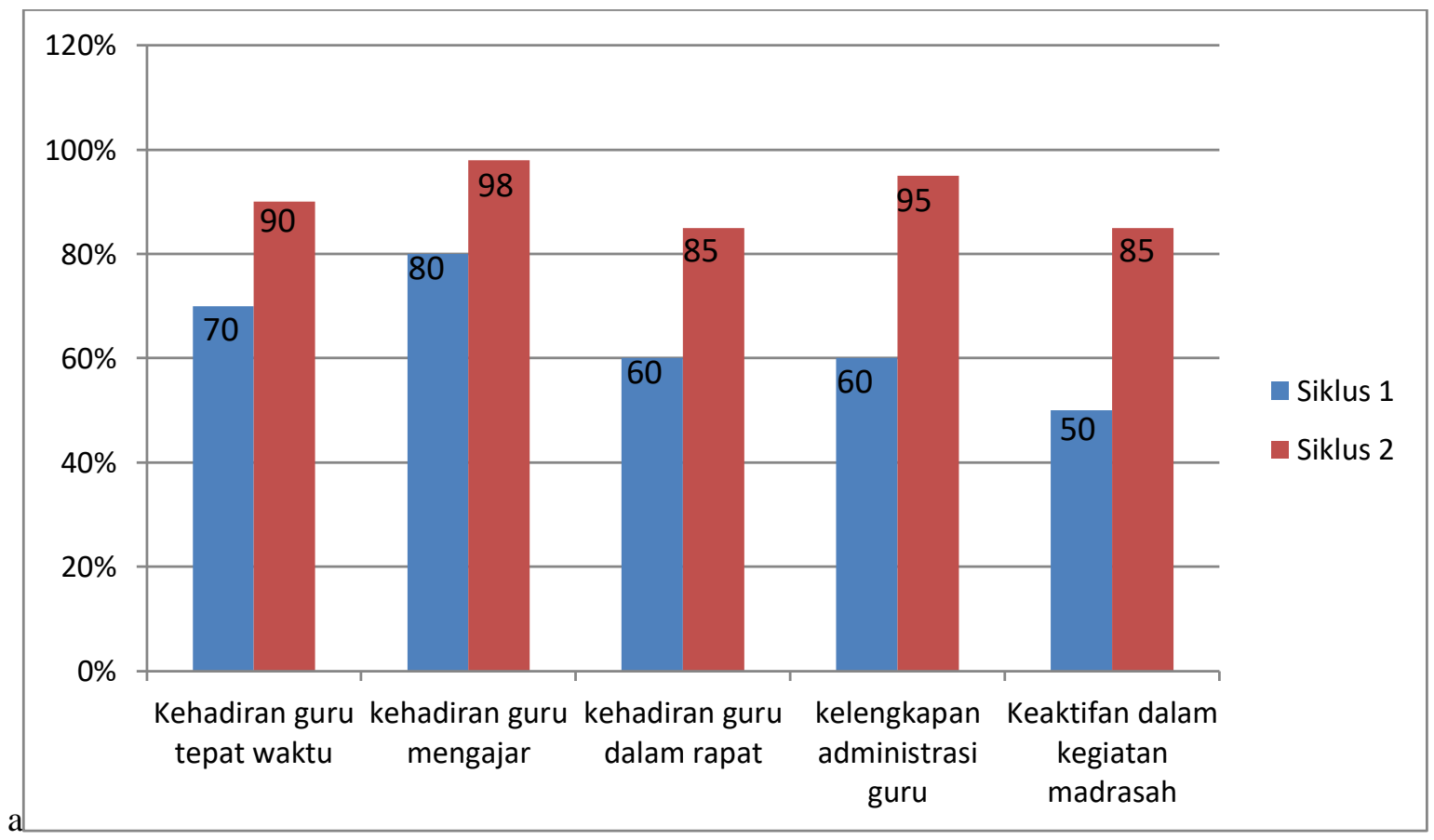

Gambar Meningkatnya Kinerja Guru dari Siklus I ke siklus II 
1287 Upaya Meningkatkan Kinerja Guru Melalui Reward dan Punishment di Madrasah - Abdul Latif Hutagaol, Sri Rezeqi Rafiqah Wardah, Neliwati

DOI: https://doi.org/10.31004/edukatif.v4i1.2159

Dari gambar di atas, diketahui bahwa terdapat peningkatan kinerja guru secara bertahap. Hal ini senada dengan penelitian yang dilakukan oleh Ritonga \& Prasetyo (2019:37-51), bahwa sistem reward dan punishment efektif untuk meningkatkan kinerja guru di pesantren dan lembaga pendidikan lainnya. Upaya peningkatan kinerja guru melalui sistem reward dan punishment juga telah diteliti oleh Fadli (2021), bahwa tidak hanya prestasi belajar siswa, kinerja guru juga efektif dalam peningkatan kinerja guru. Hal ini didasarkan pada nilai motivasi eksternal dalam sistem ini.

\section{KESIMPULAN}

Hasil penelitian menunjukkan bahwa Implementasi reward yang diterapkan di MTs Qur'an Kisaran berupa penghargaan finansial seperti tunjangan, insentif, dan bonus. Penghargaan non-finansial seperti piagam, plakat sebagai pengakuan, dan promosi jabatan. Sedangkan untuk Implementasi punishment atau hukuman berupa peringatan, teguran, pemotongan gaji, pengurangan beban kerja, pergantian amanah jabatan, hingga pemutusan hubungan kontrak kerja antara guru dengan madrasah. Hasil setelah di Implementasikannya reward dan punishment ini menghasilkan nilai positif, yakni meningkatnya kinerja guru dilihat dari menurunnya persentase kinerja belum baik, dari $36 \%$ menjadi $9,4 \%$.

\section{DAFTAR PUSTAKA}

Assingkily, M.S. 2021. Penelitian Tindakan Kelas: Meneliti Dan Membenahi Pendidikan Dari Kelas. Medan: CV. Pusdikra Mitra Jaya.

Azis, A. 2016. Reward-Punishment Sebagai Motivasi Pendidikan: Perspektif Barat Dan Islam. Cendekia, 14(2), 333-349. Http://Jurnal.Iainponorogo.Ac.Id/Index.Php/Cendekia/Article/View/830.

Bahagia, B., Habibah, N.W., Mangunjaya, F.M., \& Wibowo, R. 2021. Religion Value And Social Capital For Resilience To Combat Covid-19 In Society Environment. Edukatif: Jurnal Ilmu Pendidikan, 3(5). Https://Edukatif.Org/Index.Php/Edukatif/Article/View/705.

Bleotu, V., \& Maria, T.D. 2014. Strategic Priorities For Education Funding. Procedia-Social And Behavioral Sciences, 116(1), 2231-2234. Https://Doi.Org/10.1016/J.Sbspro.2014.01.549.

Budiningsih, A. 2005. Belajar Dan Pembelajaran. Jakarta: Rineka Cipta.

Fadli, F. 2021. Implementasi Reward Dan Punishment Dalam Meningkatkan Kinerja Guru. Lampung: UIN Raden Intan Lampung.

Khairi, M.Y. 2021. Pelatihan Melalui Webinar Sebagai Upaya Peningkatan Kinerja Dan Kualitas Guru Di Masa Pandemi. Edukatif: Jurnal Ilmu Pendidikan, 3(4). Https://Edukatif.Org/Index.Php/Edukatif/Article/View/1334.

Laily, N. 2021. Upaya Guru PAI Dalam Meningkatkan Kemampuan Kognitif Siswa Pada Mata Pelajaran Fiqih Di Masa Pandemi Covid-19. Edukatif: Jurnal Ilmu Pendidikan, 3(4) Https://Edukatif.Org/Index.Php/Edukatif/Article/View/596.

Mahirah, B., \& Fatnah, F. 2018. Pengaruh Supervisi Kepala Sekolah Terhadap Disiplin Kerja Pegawai Di SMP Negeri 1 Amali Kecamatan Amali Kabupaten Bone. Jurnal Idaarah, 2(1), 37-49. Http://Journal.Uin-Alauddin.Ac.Id/Index.Php/Idaarah/Article/View/5148.

Mangkuprawira, S. 2004. Manajemen Sumber Daya Manusia Strategik, (4th Ed.). Jakarta: Ghalia Indonesia.

Rahman, S. 2017. Pendidik Dan Pengembangan Profesi. IDARAH: Jurnal Pendidikan Dan Kependidikan, 1(1), 31-47. Https://Ejurnal.Iainlhokseumawe.Ac.Id/Index.Php/Idarah/Article/View/251. 
1288 Upaya Meningkatkan Kinerja Guru Melalui Reward dan Punishment di Madrasah - Abdul Latif Hutagaol, Sri Rezeqi Rafiqah Wardah, Neliwati

DOI: https://doi.org/10.31004/edukatif.v4i1.2159

Ritonga, M.A., \& Prasetyo, M.A.M. 2019. Peningkatan Kinerja Guru Pesantren Melalui Sistem Reward Dan Punishment. Idarah: Jurnal Pendidikan Dan Kependidikan, 3(1), 37-51. Https://Ejurnal.Iainlhokseumawe.Ac.Id/Index.Php/Idarah/Article/View/611.

Rivai, V. 2015. Manajemen Sumber Days Manusia, Edisi Ketiga. Jakarta: Rajagrafindo Persada.

Simamora, H. 2000. Manajemen Sumber Daya Manusia. Yogyakarta: STYKN.

Simamora, H. 2012. Manajemen Sumber Daya Manusia. Yogyakarta: STIE YKPN.

Siregar, F.A. 2017. Membangun Loyalitas Tenaga Pendidik. IDARAH: Jurnal Pendidikan Dan Kependidikan, 1(1), 117-128. Https://Ejurnal.Iainlhokseumawe.Ac.Id/Index.Php/Idarah/Article/View/256.

Suryadilaga, R.M., Al Musadieq, M., \& Nurtjahjono, G.E. 2016. Pengaruh Reward Dan Punishment Terhadap Kinerja: Studi Pada Karyawan PT. Telkom Indonesia Witel Jatim Selatan Malang. Jurnal Administrasi Bisnis (JAB), 39(1), 156-163.

Susanti, E. 2021. Kontribusi Kompetensi Manajerial Kepala Sekolah Dan Iklim Kerja Terhadap Kinerja Guru. Edukatif: Jurnal Ilmu Pendidikan, 3(5). Https://Edukatif.Org/Index.Php/Edukatif/Article/View/779.

Syahana, S., \& Andromeda, A. 2021. Pengembangan Instrumen Tes Two Tier Berbasis Higher Order Thinking Skills Pada Materi Sifat Koligatif Larutan Untuk Siswa SMA/MA. Edukatif: Jurnal Ilmu Pendidikan, 3(3). Https://Edukatif.Org/Index.Php/Edukatif/Article/View/505.

Timpe, A.D. 2002. Seri 6 Manajemen Sumber Daya Manusia, Kinerja. (5th Ed.). Jakarta: Elex Media Komputindo.

Wahyudi, I., \& Neviyarni, N. 2021. Analisis Terhadap Perhatian Dan Belajar Perseptual Dalam
Aktivitas
Belajar
Siswa.
Edukatif:
Jurnal
Ilmu
Pendidikan,
3(1).

Https://Edukatif.Org/Index.Php/Edukatif/Article/View/231. 